\title{
ULOGA INDIVIDUALNIH ČIMBENIKA U POVEZANOSTI EKONOMSKIH TEŠKOĆA I ISHODA KOD ADOLESCENATA ${ }^{2}$
}

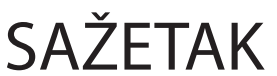

Postoji duga tradicija društvenih znanosti u proučavanju utjecaja ekonomskih teškoća na život i razvoj pojedinaca. Siromaštvo i ekonomske teškoće obitelji povezani su s nizom eksternaliziranih i internaliziranih problema mladih te njihovih obrazovnih ishoda. Uz važne obiteljske i druge socijalno-kontekstualne procese koji su u pozadini ove povezanosti, važnu ulogu imaju i individualne karakteristike djece, adolescenata i roditelja. U ovom radu naglasak je na pregledu recentnih nalaza o ulozi kognitivnih sposobnosti, ličnosti i otpornosti djece i mladih u povezanosti između ekonomskih teškoća i ishoda adolescenata. Posebno je naznačena odgovornost istraživača u društvenim, biomedicinskim i interdisciplinarnim znanostima koji se bave proučavanjem ekonomskih teškoća kada se radi o utjecaju na

\footnotetext{
'Ines Rezo, psihologinja, e-mail: irezo@pravo.hr

2 Ovaj rad financirala je Hrvatska zaklada za znanost projektom »Ekonomske teškoće obitelji, psihosocijalni problemi i obrazovni ishodi adolescenata u vrijeme ekonomske krize« [IP-2014-09-8546].
}

Pregledni članak

Primljeno: listopad, 2016.

Prihvaćeno: studeni, 2016.

UDK 364.1: 159.922 .8

DOI 10.3935/ljsr.v23i2.139

Ines Rezo'

Sveučilište u Zagrebu

Pravni fakultet

Studijski centar socijalnog rada
Ključne riječi:

ekonomske teškoće obitelji, psihosocijalni ishodi, zaštitni i rizični čimbenici, adolescenti. 
Ljetopis socijalnog rada 2016., 23 (2), 165-186 str. kreiranje socijalnih politika i aktivnog mijenjanja okolnosti pojedinaca pogo-
đenih ekonomskim teškoćama.

\section{UVOD}

U bogatoj literaturi vezanoj za istraživanje utjecaja siromaštva i ekonomskih teškoća na život obitelji, postoji i bogata zbrka ovih pojmova. Najčešće definicije siromaštva dijele siromaštvo na apsolutno i relativno. Apsolutno siromaštvo definira se kao nemogućnost zadovoljenja osnovnih potreba, dok relativno siromaštvo predstavlja nemogućnost zadovoljenja potreba ili sudjelovanja u aktivnostima koje čine dio prihvatljivog životnog standarda (Leksikografski zavod Miroslav Krleža, 2016.). Prema drugoj definiciji, ekonomske teškoće predstavljaju komponentu koncepta siromaštva (Cauthen i Fass, 2008.). Korištenjem koncepta ekonomskih teškoća zahvaćamo širi raspon ljudi koji žive s različitim ekonomskim teškoćama, a da pri tome ne moraju zadovoljavati različite linije siromaštva koje funkcioniraju na principu rigidne crte razgraničenja između ljudi koji žive u siromaštvu i ljudi koji ne žive u siromaštvu. Gledanjem na siromaštvo samo kroz prizmu apsolutnog siromaštva, dovodimo se u opasnost da gubimo iz fokusa činjenicu promjenjivosti životnog standarda obitelji koji može varirati iz mjeseca u mjesec. Pri tome je važno obratiti pažnju i na subjektivnu percepciju ekonomskih teškoća koja se pokazuje direktnije povezana s različitim negativnim ishodima obitelji koje doživljavaju ekonomske teškoće, od samih objektivnih pokazatelja (Šućur i sur., 2015.).

Jasno, iz raznolikih tumačenja ekonomskih teškoća i siromaštva, proizlaze i različite mjere ovih koncepata. Najčešće korištene mjere u istraživanjima ekonomskih teškoća usko su povezane sa socioekonomskim statusom (Conger, Conger i Martin, 2010.). Socioekonomski status je konstrukt koji predstavlja različite dimenzije društvenog položaja, uključujući prestiž, moć i ekonomsku dobrobit (Conger, Conger i Martin, 2010.). Većina suvremenih istraživača suglasna su oko tri kvantitativna pokazatelja koja pokrivaju navedene dimenzije: prihodi, obrazovanje i zanimanje članova kućanstva (Bradley i Corwyn, 2002.). Ujednačeno korištenje ovih pokazatelja, uz subjektivnu percepciju ekonomskih teškoća, može pridonijeti lakšoj usporedbi istraživanja područja i u konačnici jasnijim smjernicama za praktični rad s obiteljima koja prolaze kroz ekonomske teškoće.

Negativni ishodi djece u obiteljima koje doživljavaju ekonomske teškoće vezani su uz cjelokupni dječji razvoj: tjelesne i zdravstvene teškoće, zastoj u kognitivnom, socijalnom i emocionalnom razvoju, kao i obrazovne teškoće, što sveukupno negativno djeluje na život djece i njihovo samostalno funkcioniranje u budućnosti, a time i negativno na društvo u cjelini.

\section{6 članci}


Tema utjecaja ekonomskih teškoća obitelji na zdravlje djece posebno dolazi do izražaja u kontekstu ekonomske krize koja je započela 2008. godine, a čije su posljedice prisutne i danas. Termini koje vežemo uz ekonomsku krizu su nezaposlenost, nesigurnost, promjena, iseljavanje, mjere štednje. U mnogim zemljama prisutne su različite mjere štednje koje često za posljedicu imaju još veće socioekonomsko ugrožavanje ionako ugroženih skupina. U psihologiji je opsežno i često istraživano kakav je odnos nezaposlenosti i ekonomskih teškoća u kontekstu odraslih, nezaposlenih ljudi (npr. Galić, Maslić Seršić i Šverko, 2006.). S obzirom na dugotrajne odjeke koje ekonomska kriza ima, važno je provjeriti njezin utjecaj na djecu i mlade koji snose njezine posljedice.

\section{PSIHOSOCIJALNI ISHODI ADOLESCENATA}

Pojam »psihosocijalni« vrlo je popularan u raznim društvenim znanostima. Zbog toga se može dogoditi da znači puno toga ili da ne znači ništa, što nikako nije u duhu znanstvenih načela preciznosti i provjerljivosti. Zbog toga je važno jasno naznačiti što pojam znači. Prema Yule i sur. (2004.), pojam psihosocijalni naglašava dinamičan odnos između psiholoških i socijalnih učinaka, pri čemu jedni neprestano utječu na druge, i obrnuto. Prema tome, važno je osobu promatrati u kontekstu integracije psiholoških komponenti mišljenja, emocija i ponašanja, kao i socijalnih komponenti okoline, kulture, ekonomije, tradicije, duhovnosti, međuljudskih odnosa i životnih zadataka.

Osim toga, Svjetska zdravstvena organizacija (WHO, 1948.) definira zdravlje kao stanje cjelokupne fizičke, mentalne i socijalne dobrobiti, što upućuje na povezanost pojma psihosocijalnog stanja s općom dobrobiti osobe (Martikainen, Bartley i Lahelma, 2002.). No unatoč toj povezanosti, psihosocijalni ishodi korišteni u istraživanjima uglavnom se odnose na negativne ishode.

Tako su često korišteni psihosocijalni ishodi kod djece i adolescenata različiti: (1) internalizirani problemi - anksioznost, depresivnost, doživljaj stresa, (2) eksternalizirani problemi - nasilno i delinkventno ponašanje, konzumacija alkohola i droga, kockanje i rizične seksualne aktivnosti te (3) obrazovni ishodi - školske ocjene, neopravdani izostanci, opomene i ukori, napuštanje srednjoškolskog obrazovanja.

Postoji inicijativa istraživača koji upozoravaju na važnost istraživanja pozitivnih ishoda. Predlažu istraživanje sljedećih ishoda (Lippman, Anderson Moore i McIntosh, 2009.): socijalne vještine (empatija, socijalne kompetencije), adekvatni društveni odnosi (pozitivan odnos s roditeljima, vršnjačka prijateljstva), adekvatno funkcioniranje u školskom i poslovnom okruženju (marljivost i pouzdanost, angažiranost, inicijativa i proaktivnost, štedljivost, pouzdanost i integritet), pomaganje 
drugima u pozitivnom razvoju (altruizam, velikodušnost), osobni razvoj (opraštanje, orijentacija prema cilju, zahvalnost, nada, zadovoljstvo životom, osjećaj svrhovitosti, duhovnost). Istraživači se zalažu barem za kombiniranje istraživanja pozitivnih i negativnih ishoda. Zaista, postavlja se pitanje o opravdanosti isključivog istraživanja negativnih ishoda ili zaključivanja o pozitivnim ishodima na temelju toga da dijete ili mlada osoba naprosto ne pokazuje negativne ishode koji su najčešće proučavani. Na to pitanje psihologija tek počinje odgovarati. S obzirom na puno veći opseg istraživanja koja su se bavila negativnim psihosocijalnim ishodima, u ovom radu ćemo se usmjeriti na njih.

Istraživanja utjecaja ekonomskih teškoća na psihosocijalne ishode djece $\mathbf{i}$ mladih datiraju također iz vremena ekonomske krize - Velike depresije 1930-ih godina, kada je niz istraživanja otvorio priču o efektima siromaštva na lošije funkcioniranje cjelokupne obitelji, kao i života roditelja i djece (Angell, 1936., Cavan i Ranck, 1938., Komarovsky, 1940., prema Conger i Donnellan, 2007.). Od tada su u istraživanjima važnu ulogu zauzele individualne karakteristike djece, adolescenata i roditelja. Adekvatan primjer toga je Heckman (2008.) koji izvlači zaključke iz niza svojih istraživanja o djeci koja odrastaju u ekonomskim teškoćama. On zaključuje da su kognitivne sposobnosti, socioemocionalne vještine, fizičko i mentalno zdravlje, ustrajnost, pažnja, motivacija i samopouzdanje osobe sve važne determinante socioekonomskog statusa. Usmjerava se na prevencijske programe u ranom djetinjstvu čiji cilj je obogaćivanje okoline djece i poticanje pravilnog ranog razvoja što ima implikacije na djetetov kasniji razvoj i relevantne ishode u životu (Heckman, 2008.).

$\mathrm{U}$ ovom radu naglasak je na nalazima o ulozi kognitivnih sposobnosti, ličnosti i otpornosti djece i mladih u povezanosti između ekonomskih teškoća i ishoda adolescenata, uzimajući u obzir i kontekstualne čimbenike koji posreduju ovom odnosu.

\section{TEORIJSKI OKVIRI}

U proučavanju povezanosti ekonomskih teškoća obitelji i psihosocijalnih ishoda adolescenata postoji nekoliko teorijskih okvira koji su vrijedni za razumijevanje ove teme. U ovom radu bit će izdvojeni Ekološki model ljudskog razvoja (Bronfenbrenner, 1979.) te Model obiteljskog stresa (Conger i sur., 1994.) kao primjeri sveobuhvatnih i dobro potvrđenih modela u ovom području. Ekološki model ljudskog razvoja (Bronfenbrenner, 1979.) pruža cjelovit pogled na prilagodbu i poteškoće mladih. On opisuje kako različite razine ekološkog sustava (adolescent, obitelj, škola, susjedstvo) utječu na pozitivan razvoj djeteta.

\section{8 članci}


Ines Rezo: Uloga individualnih čimbenika u povezanosti ekonomskih teškoća...

Ekološki model može se povezati s modelom specifično vezanim za ovo područje - modelom obiteljskog stresa (Conger i sur., 1994.). Model obiteljskog stresa (eng. Family stress model - FSM) dovodi u vezu ekonomske teškoće i obiteljski stres, kroz uvećanje emocionalnih teškoća roditelja i ugrožavanje zdravog razvoja djece. Istraživanja temeljena na FSM modelu usmjerena su na stariju djecu i adolescente te bolje objašnjavaju različite psihosocijalne probleme $u$ adolescenciji nego u ranijoj dobi djece (Conger, Conger i Martin, 2010.).

\section{Ekološki model ljudskog razvoja}

Urie Bronfenbrenner (1979.) postavio je ekološki model ljudskog razvoja i već tada postavio temelj proučavanja utjecaja siromaštva na život djece, uzimajući u obzir cjelokupni kontekst dječjeg razvoja i odrastanja. Po njegovom modelu, dijete živi u ekološkom okruženju - koncentričnim strukturama koje su u interakciji. Svaki koncentrični krug reprezentira sustav ili podsustav koji je sastavni dio života pojedinca. U mikrosustavu se nalazi dijete sa svojim individualnim osobinama te osobe koje su mu najbliže; njegova bliža i dalja obitelj, osobe iz vrtića i škole, susjedi. Mezosustav čine veze između pojedinih aspekata u mikrosustavu. Egzosustav je socijalna struktura u kojoj dijete živi, zajedno sa svojom obitelji. Odnosi se, primjerice, na radnu i životnu okolinu roditelja i obitelji, značajke lokalne zajednice, socijalnu mrežu roditelja, a sveukupno može imati velik utjecaj na život djeteta. Makrosustav se odnosi na najudaljeniji sloj u sustavu koji predstavlja karakteristike društva, ekonomske uvjete, kulturu, zakone i politiku.

Možemo vidjeti da djeca i mladi koji žive u obiteljima s ekonomskim teškoćama mogu zbog toga biti suočeni s različitim preprekama kroz sva četiri ekosistema, a da pri tome imaju vrlo malu ili nikakvu moć nad tim preprekama. Ipak, postoje djeca i mladi koji pokazuju pozitivne ishode, unatoč teškoćama s kojima se susreću. Stoga je posebno važno razmatrati osobne karakteristike pojedinca u cjelokupnom kontekstu njegovog odrastanja kako bismo povećali razumijevanje i na koncu unaprijedili strategije pružanja podrške i pomoći djeci i obiteljima koje se suočavaju s ekonomskim teškoćama.

\section{Model obiteljskog stresa (Family stress model - FSM)}

Model obiteljskog stresa (eng. Family stress model - FSM; Conger i sur., 1994.) povezuje ekonomske teškoće i obiteljski stres, kroz utjecaj na emocionalne teškoće roditelja i ugrožavanje zdravog razvoja djece. 
Kako je vidljivo iz Slike 1., polazeći od apsolutne razine prihoda i ekonomskih resursa, model povezuje ponašanje roditelja i prilagodbu djece kroz niz uzajamno povezanih medijatorskih varijabli. Ekonomske teškoće dovode do ekonomskog pritiska (percipirane teškoće u nošenju sa zahtjevima da se osigura zadovoljavanje temeljnih životnih potreba) te zbog toga dolazi do frustracije, ljutnje i emocionalnog stresa roditelja. Povećani ekonomski pritisak povezan je $s$ narušavanjem mentalnog zdravlja roditelja i povećanim sukobima među njima. To dovodi do smanjene uključenosti i skrbi roditelja za djecu te do češćeg korištenja nasilnih postupaka. Završno, ekonomske teškoće utječu na psihosocijalnu prilagodbu djece kroz emocionalni stres roditelja, njihove bračne odnose i kapacitet za roditeljstvo.

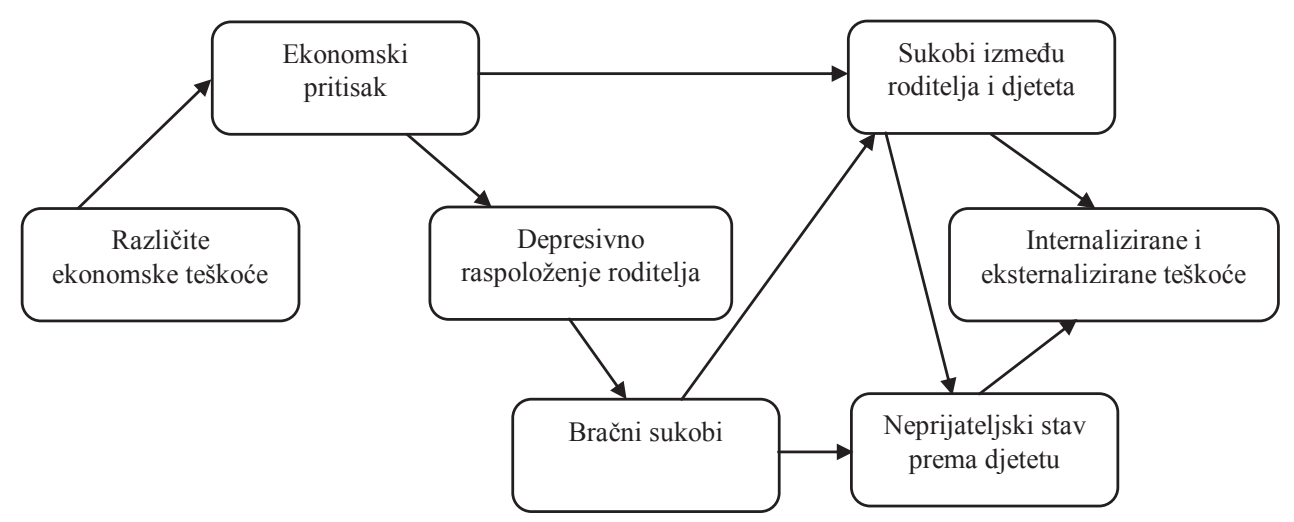

Slika 1. Model obiteljskog stresa (Conger i sur., 1994.)

Conger (1994.) postavlja Model obiteljskog stresa koji pruža mogućnosti za mnogobrojna istraživanja čimbenika i ishoda ekonomskih teškoća obitelji na djecu. Tako niz istraživanja potvrđuje povezanost ekonomskih teškoća s akademskim neuspjehom djece (Ferić, Milas i Rihtar, 2010.; Gregurović i Kuti, 2010.; KuterovacJagodić, Keresteš i Brković, 2013.; Landers-Potts i sur., 2015.), internaliziranim problemima (Conger i sur., 2002.; McLeod i Shanahan, 1993.), eksternaliziranim problemima (Ajduković i Rajhvajn-Bulat, 2012.; Conger i sur., 1994.) i socijalnim razvojem (Conger i sur., 2002.; Raboteg-Šarić, Brajša-Žganec i Šakić, 2009.).

Uslijed povećanog broja istraživanja koja su ukazivala na prediktivnost osobina ličnosti u sferi nošenja s ekonomskim teškoćama (Roberts, Caspi i Moffitt, 2003.; Roberts i sur., 2007.), autori su naknadno proširili ovaj model s glavnim i moderirajućim učincima osobnih karakteristika u sve procese modela obiteljskog stresa (Conger i Donnellan, 2007.; Donnellan i sur., 2009.). Iz Slike 2. vidljivo je da su

\section{0 članci}


osobne karakteristike roditelja izravno povezane s glavnim komponentama Modela obiteljskog stresa - ekonomskim pritiskom, odnosom roditelja i roditeljskim postupcima prema djetetu, te da zajednički djeluju na ishode kod djece. Autori su ipak samo djelomično preuzeli diferencijalni pristup u svom modelu gdje nisu uzeli u obzir osobine djece i mladih na neposredne i trenutne psihosocijalne ishode, već su se odlučili promatrati utjecaj osobina roditelja na sljedeću generaciju - njihove djece. Ovaj pristup ima dakako svoje prednosti u predviđanju dugoročnih ishoda, no ostaje pitanje utjecaja osobina djece na njihovu trenutnu prilagodbu u kontekstu ekonomskih teškoća.

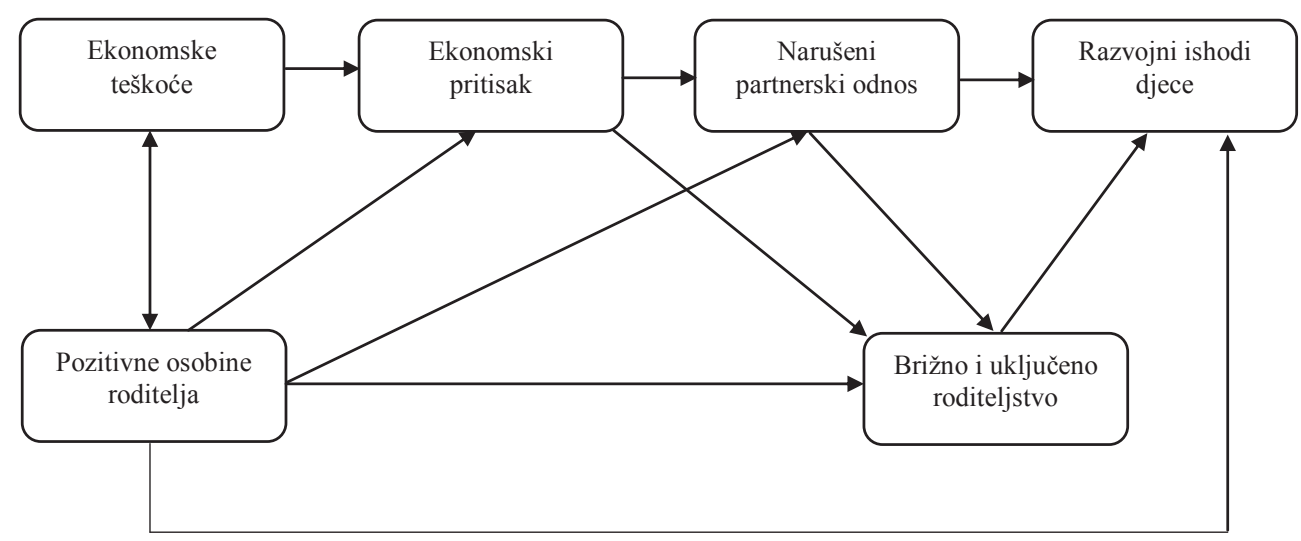

Slika 2. Transakcijski model povezanosti osobnih karakteristika, ekonomskih teškoća, interpersonalnih odnosa i ishoda djece (Conger i Donnellan, 2007.)

\section{ULOGA INDIVIDUALNIH ČIMBENIKA U POVEZANOSTI EKONOMSKIH TEŠKOĆA I POZITIVNIH ISHODA KOD DJECE I MLADIH}

Karakteristike djeteta koje su povezane s pozitivnim ishodima uključuju inteligenciju, regulaciju emocija, temperament i ličnost, strategije suočavanja, lokus kontrole, pažnju i genetske utjecaje (Masten i Powell, 2003.). Detaljnije ćemo promotriti kognitivne sposobnosti i ličnost te otpornost, kao krovni pojam koji predstavlja adekvatnu prilagodbu pojedinca u suočavanju s teškoćama i izazovima koji nadilaze uobičajene razvojne zadatke (Masten, 2001.). 


\section{Kognitivne sposobnosti}

U svom preglednom radu povodom 100. godišnjice Spearmanovog prvog predstavljanja pojma opće inteligencije, Lubinski (2004.) sažima psihologijska nastojanja o povezivanju kognitivnih sposobnosti s nizom relevantnih varijabli te navodi da su individualne razlike u kognitivnim sposobnostima procijenjene u ranoj dobi, među ostalim, uzročno povezane sa socioekonomskim statusom, delinkvencijom, rizičnim ponašanjima, akademskim uspjehom te kvalitetom života.

Utvrđeno je da kognitivne sposobnosti djece predviđaju niz pozitivnih ishoda u njihovim životima, uključujući akademsko postignuće, prosocijalno ponašanje, socijalnu kompetenciju (Masten i Coatsworth, 1998.), kao i odsutnost niza negativnih ishoda, poput antisocijalnog ponašanja (White, Moffitt i Silva, 1989.) i drugih vrsta psihopatologije (Radke-Stolisnik i Brown, 1993., Tiet i sur., 1998., 2001., Werner i Smith, 1992., prema Vanderbilt-Adrianceand, Shaw, 2008.). Postoji nekoliko razloga zbog kojih se kognitivne sposobnosti izdvajaju kao zaštitni faktor u životima djece. Djeca s visokim kognitivnim sposobnostima vjerojatno posjeduju i učinkovite vještine procesiranja informacija i rješavanja problema, što im omogućuje lakše nošenje s izazovima u okolini (Vanderbilt-Adriance i Shaw, 2008.) te češće postižu akademske uspjehe što je pak povezano s lakšim prihvaćanjem društvenih normi i njihovom integracijom u relevantne vršnjačke grupe (Masten i Coatsworth, 1998.). lako je niz istraživanja dosljedno pokazao da su kognitivne sposobnosti važnije kao prediktori u rizičnim okolnostima, nego u predviđanju pozitivnih ishoda (Masten i Coatsworth, 1998.; Tiet i sur., 2001.), istraživanje Luthar (1991.) s uzorkom djece koja su odrastala u gradovima u unutrašnjosti SAD-a pokazalo je da su visoke kognitivne sposobnosti povezane samo s pozitivnim ishodima u kontekstima odrastanja s niskorizičnim životnim događajima, dok su u kontekstu visokostresnih situacija nisu pokazale prediktivnima.

U istraživanjima koja su se bavila povezanošću socioekonomskog statusa s kognitivnim sposobnostima i dobrobiti djece, nalazi su jednoznačni. Djeca koja odrastaju u ekonomskim teškoćama pokazuju niže rezultate na testovima inteligencije, znanja jezika te akademskog uspjeha, u usporedbi s djecom koja odrastaju u prosječnim ili iznadprosječnim ekonomskim uvjetima (Bradley i Corwyn, 2002.; Jefferis, Power i Hertzman, 2002.; Linver, Brooks-Gunn i Kohen, 2002.). Osim toga, djeca koja odrastaju u ekonomskim teškoćama imaju veću vjerojatnost izgubiti godinu školovanja, pohađati posebne oblike obrazovanje ili napustiti školovanje, u usporedbi s djecom koja odrastaju u prosječnim ili iznadprosječnim ekonomskim uvjetima (McLoyd, 1998.).

Dugoročnost posljedica takvih razlika vidljiva je u istraživanjima koja pokazuju da su razlike u školskom postignuću između djece različitog socioekonomskog sta-

\section{2 članci}


tusa povezane s ishodima u odrasloj dobi, poput zapošljavanja i visine plaće, kao i zdravstvenim problemima te očekivanoj životnoj dobi (Lager, Bremberg, i Vagero, 2009.).

Mehanizme povezanosti između socioekonomskog statusa i kognitivnih sposobnosti kod djece vjerojatno je moguće objasniti različitim čimbenicima. Istraživači u ovom području bavili su se ulogom obiteljskih čimbenika, poput razine kognitivne stimulacije, roditeljskog stila te roditeljskog stresa, u objašnjavanju ovih mehanizama povezanosti (Guo i Harris, 2000.; McCulloch i Joshi, 2001.). Pokazali su da razina kognitivne stimulacije kod kuće objašnjava dio povezanosti socioekonomskog statusa obitelji i djetetovih kognitivnih sposobnosti, što nas dovodi do pitanja učinka naslijeđa (eng. nature) ili okoline (eng. nurture).

Odgovore na to pitanje valja potražiti u područjima neuroznanosti i epigenetike - područja molekularne biologije koje proučava epigenetičke biljege čija je uloga uključivanje ili isključivanje gena u organizmu (Ajduković i Rajter, 2014.).

Tako Clay (2015.) ukazuje u APA publikacijama na povećani interes psihologa i neuroznanstvenika za istraživanja utjecaja siromaštva na razvoj mozga i dugoročne zdravstvene rizike. Recentna istraživanja govore o utjecaju roditeljskog stresa na promjene genetskog obrasca djece i razvoja mozga (McEwen, 2008.; Essex i sur., 2013.). Istraživanja Centra za neuroznanosti i društvo Sveučilišta Pennsylvania (Hackman i sur., 2015.) pokazuju da je razvoj prefrontalnog korteksa djece vrlo osjetljiv na faktore okoliša, kao što su stres, nedostatak kognitivne stimulacije, loša prehrana i razlike u dostupnosti i kvaliteti zdravstvene skrbi. Razlike u razvoju mozga očituju se u dječjem radnom pamćenju, rješavanju problema i drugim izvršnim funkcionalnim vještinama.

lako je pitanje nasljednosti kognitivnih sposobnosti u djetinjstvu neupitno (McGue, Bacon i Lykken, 1993.), pitanja veličine efekta, mehanizama pa i implikacija nasljednosti intelektualnih sposobnosti nedovoljno su jasno odgovorena. Povijesno gledano, implikacije zagovaranja isključivo genetskih predispozicija inteligencije postavljala su ozbiljna ograničenja za učinkovitost bilo kakvih programa u svrhu povećavanja intelektualnih sposobnosti. Današnji istraživači slažu se da su sve individualne karakteristike, pa tako i inteligencija, pod utjecajem okruženja pod kojim dijete odrasta (Vanderbilt-Adriance i Shaw, 2008.), čemu posebnu težinu stavljaju i nalazi prethodno spomenutih neuroznanstvenih i epigenetičkih istraživanja.

Zanimljiva pitanja o načinima utjecaja socioekonomskog statusa na kognitivne sposobnosti kod djece postavlja Guo (1998.). Je li baš djetinjstvo kritično razdoblje do čijeg završetka utjecaji kumulativnog siromaštva izvrše svoj maksimum na dječje kognitivne sposobnosti i postignuća ili su kognitivni ishodi više funkcija duljine izloženosti siromaštvu (što je duža izloženost siromaštvu, to je veći utjecaj 
na kognitivne sposobnosti) bez obzira na životnu fazu u kojoj je dijete izloženo siromaštvu? Pri tome Guo (1998.) razlikuje kognitivne sposobnosti od kognitivnih postignuća. Kognitivne sposobnosti predstavljaju stabilnije individualne osobine od postignuća određene i okolinskim i genetskim faktorima u ranom djetinjstvu. Kognitivna postignuća su pak više naučena te nastaju kao funkcija sposobnosti, ali i motivacije i mogućnosti djeteta. Rezultati istraživanja razjašnjavaju kompleksnost ove povezanosti. Dugoročno siromaštvo ima značajne efekte i na kognitivne sposobnosti i na postignuće, ali u različitim razvojnim fazama kod djece. Čini se da je djetinjstvo znatno važniji period za razvoj kognitivnih sposobnosti od rane adolescencije, dok iskustvo siromaštva u adolescenciji ima važniji utjecaj na kognitivna postignuća. Sukladno razvojnim teorijama, djetinjstvo je ključno razdoblje za razvoj kognitivnih sposobnosti pa siromaštvo u toj fazi ima veći utjecaj na njih, dok siromaštvo doživljeno u ranoj adolescenciji ima veći utjecaj na kognitivna postignuća jer su ona funkcija i motivacije i sposobnosti, a zbog prirode adolescencije kao razvojne faze, vjerojatnije je da će osiromašena okolina više utjecati na motivaciju djeteta kada postane adolescent. Razumijevanje perioda utjecaja siromaštva na dječje kognitivne ishode ima važne implikacije na kreiranje socijalnih politika.

Zaključno, varijable kognitivnih sposobnosti nameću se kao važne u proučavanju utjecaja ekonomskih teškoća na psihosocijalne i obrazovne ishode kod djece i adolescenata. Kako je navedeno, osim što imaju utjecaj na trenutne ishode mlade osobe koja živi u ekonomskim teškoćama, njihov utjecaj vidljiv je i u odrasloj dobi.

\section{Ličnost}

»Ličnost je skup psihičkih osobina i mehanizama unutar pojedinca koji su organizirani i relativno trajni te utječu na interakcije i adaptacije pojedinca na intrapsihičku, fizičku i socijalnu okolinu« (Larsen i Buss, 2008.: 4).

lako postoji cijeli niz teorija i modela ličnosti, usmjerit ćemo se na petofaktorski model ličnosti kao jedan od najčešće korištenih modela u istraživanjima (Costa i McCrae, 1994.) u proučavanju uloge u međuodnosu ekonomskih teškoća i ishoda kod djece i adolescenata. Petofaktorski model ličnosti opisuje ličnost kroz pet glavnih osobina - neuroticizam, ekstraverziju, savjesnost, ugodnost i otvorenost prema iskustvu. Potvrđen je u nizu istraživanja, unatoč varijacijama u istraživačkim metodama, instrumentima, uzorcima, jezicima i kulturama (Goldberg i John, 1990., McCrae i Costa, 1997., 1999., prema Branje, van Lieshout i Gerris, 2007.), a potvrđena je i mogućnost pouzdanog procjenjivanja ovih pet osobina $u$ adolescenciji (Costa i McCrae, 1994.).

Što se tiče povezanosti petofaktorskog modela s relevantnim ishodima $u$ adolescenciji, John i sur. (1994.) u svom istraživanju istražili su povezanost osobina

\section{4 članci}


ličnosti s delinkvencijom, razvojnom psihopatologijom, školskim uspjehom, inteligencijom i socioekonomskim statusom. Njihovi nalazi pokazuju da postoji negativna povezanost delinkventnog ponašanja s ugodnošću i savjesnošću, što je sukladno nalazima Heavena (1995.) koji je uz negativnu povezanost delinkventnog ponašanja s ugodnošću i savjesnošću, pronašao i pozitivnu povezanost delinkventnog ponašanja s neuroticizmom. Ovakvi nalazi u skladu su i s nalazima na odrasloj populaciji (Costa i McCrae, 1994.). Što se tiče razvojne psihopatologije, mjerena je kroz eksternalizirane i internalizirane probleme. Eksternalizirani problemi uključivali su agresiju, krađu, laganje, nepažnju, impulzivnost i hiperaktivnost, što se također pokazalo negativno povezano $\mathrm{s}$ ugodnošću i savjesnošću, a pozitivno $\mathrm{s}$ ekstraverzijom. Internalizirani problemi karakterizirani su anksioznošću, somatizacijom i povučenošću, što je pozitivno koreliralo s neuroticizmom, a negativno sa savjesnošću. Školski uspjeh i inteligencija pozitivno su povezani s otvorenosti prema novim iskustvima i savjesnošću. Slično navodi i Poropat (2009.) u metaanalizi o povezanosti petofaktorskog modela ličnosti i školskog uspjeha gdje pokazuje da je školski uspjeh značajno pozitivno povezan s ugodnošću, savjesnošću i otvorenosti prema iskustvu. Visoka savjesnost, nizak neuroticizam, a možda čak i visoka ugodnost dio su osnovnog skupa pozitivnih osobnih karakteristika koje su povezane s otpornošću kod djece i mladih (Donnellan i sur., 2009.). Korelacije između socioekonomskog statusa i osobina ličnosti bile su gotovo nulte i nisu u skladu s dobivenom povezanosti između socioekonomskog statusa i otvorenosti prema novim iskustvima koja je pronađena u odrasloj populaciji (Costa i McCrae, 1994.).

Donnellan i sur. (2009.) pokušali su kreirati teorijski okvir za razumijevanje kako individualni čimbenici mogu ojačati otpornost na ekonomske teškoće i njihove negativne posljedice. U svom radu nastoje pomiriti dva oprečna pristupa - pristup društvene selekcije (eng. social selection) i pristup društvene uzročnosti (eng. social causation) pod okriljem ideje da razvojni ishodi nisu niti funkcija samih individualnih karakteristika, što zagovara pristup društvene selekcije, kao niti isključivo konteksta razvoja, što je načelo pristupa društvene uzročnosti. Takav je i njihov pogled na individualne karakteristike - dinamičke značajke koje imaju tendenciju razvoja u ranim životnim fazama, a u neposrednom su međuodnosu s društvenim kontekstom pojedinca (Caspi, 1998.). U istraživanju su pokazali kako postoji korelacija između savjesnosti u adolescenciji i percipiranog ekonomskog pritiska u odrasloj dobi, iako je učinak bio mali. Ostale četiri osobine ličnosti nisu dodale značajno objašnjenje ekonomskom pritisku u odrasloj dobi. Neuroticizam i mjere ekonomskog pritiska bili su povezani s manje zadovoljavajućim odnosima u odrasloj dobi. Drugi važan nalaz je da je percipirani ekonomski pritisak kod adole scenata bio povezan s ekonomskim pritiskom u ranoj odrasloj dobi sudionika, čak i kada se kontrolirao utjecaj savjesnosti i postignuća adolescenata. Autori zaključuju 
da izloženost ekonomskom pritisku u adolescenciji ima trajne posljedice za razvoj pojedinaca, iako same osobine ličnosti u njihovim istraživanjima ne pokazuju veliku mogućnost predikcije.

Istraživanja su evidentno pokazala da osobine ličnosti mogu predviđati psihosocijalne ishode djece i odraslih, ali za jasniju sliku njihove uloge u kontekstu ekonomskih teškoća, potrebno je još istraživačkog rada kako bismo jasnije mogli kreirati i intervencije koje promiču osobine ličnosti koje se pokazuju kao zaštitni faktori, što bi moglo biti korisno za pojedince i njihove obitelji generalno, a posebice za one koji doživljavaju ekonomske teškoće.

\section{Otpornost}

Tijekom posljednjih nekoliko desetljeća koncept otpornosti za mnoge istraživače postao je važan način proučavanja procesa i mehanizama povezanosti izloženosti rizičnim čimbenicima s pozitivnim i negativnim ishodima kod djece. Definirati otpornost nije lak zadatak, a različite škole i gledišta proučavaju ga katkad i iz sukobljenih strana. Posebno se izdvajaju dva gledišta na otpornost: jedno koje gleda otpornost kao stabilnu crtu ličnosti te drugo koje inzistira na proučavanju i važnosti okolinskih čimbenika koji djeluju na otpornost. Tako se prema diferencijalnom gledištu otpornost definira kao pozitivna karakteristika ličnosti koja jača prilagodbu pojedinca izazovnim ili ugrožavajućim životnim okolnostima (Wagnild i Young, 1993.). U razvojnoj znanosti, otpornost se obično definira kao pozitivna prilagodba tijekom ili nakon izloženosti teškoćama koje imaju potencijal da na različite načine naštete razvoju djece (Masten, 2007.). Iz ove perspektive promatrana je kao dinamički proces koji proizlazi iz stalne interakcije između djeteta i okoline, a ne kao isključivo unutarnja karakteristika djeteta (Luthar i Zelazo, 2003.).

Suprotstavljanje ovih dvaju gledišta poprima nove razmjere kada se radi o kreiranju socijalnih politika. Neki istraživači upozoravaju da gledanje na otpornost kao na stabilnu karakteristiku osobe može dovesti do optuživanja pojedinca za njegove negativne životne ishode (Luthar, Cicchetti i Becker, 2000.) te donositelji socijalnih politika mogu koristiti taj argument kao opravdanje za uskraćivanje socijalnih usluga djeci u riziku (Luthar i Cicchetti, 2000.).

Proučavanje otpornosti pruža informacije o uvjetima pod kojima utvrđeni rizični čimbenici nisu povezani s negativnim ishodima (Masten, 2001.). Kako otpornost promatramo u kontekstu izloženosti rizičnim čimbenicima, korisno je vidjeti što su istraživači smatrali samim rizičnim čimbenicima. $U$ istraživanjima su tako korišteni roditeljska psihopatologija (Luthar i Sexton, 2007.), ekonomske teškoće (Buckner, Mezzacappa i Beardslee, 2003.; Kim-Cohen i sur., 2004.), urbano siromaštvo i nasilje u zajednici (Gorman-Smith, Henry i Tolan, 2004.), negativni

\section{6 članci}


životni događaji (D'Imperio, Dubow i Ippolito, 2000.), zlostavljanje djece (Jaffee i sur., 2007.) te kumulativni indeksi rizika (Seifer i sur., 1992.).

S druge strane, važno je proučiti i ulogu zaštitnih čimbenika u otpornosti. Zaštitni čimbenici definirani su kao karakteristike djeteta, obitelji i šireg okruženja koje smanjuju negativne učinke teškoća na ishode kod djece (Masten i Reed, 2002.). Možemo ih promatrati kroz tri područja: (1) karakteristike unutar samog djeteta, (2) karakteristike unutar obitelji i (3) karakteristike zajednice (VanderbiltAdriance i Shaw, 2008.).

Kako je prethodno navedeno, karakteristike djeteta povezane s pozitivnim ishodima uključuju visoku inteligenciju, regulaciju emocija, temperament i ličnost s karakteristikama adaptabilnosti i društvenosti, pozitivne strategije suočavanja, internalni lokus kontrole, adekvatnu pažnju i zdrave genetske utjecaje (Masten i Powell, 2003.). Važno je imati na umu činjenicu da karakteristike djeteta mogu biti zaštitni čimbenici, ali su nužno pod utjecajem vanjskih čimbenika, poput obiteljskog okruženja i cjelokupnog konteksta u kojem dijete živi. Prema tome, ne možemo ih promatrati isključivo kao rezultat genetskog utjecaja (Vanderbilt-Adriance i Shaw, 2008.).

Zaštitni čimbenici unutar obitelji su kvaliteta odnosa roditelja i djece i privrženost (Luthar i Latendresse, 2005.), roditeljski stil obilježen toplinom i responzivnošću (Kim-Cohen i sur., 2004.) te veća količina roditeljskog nadzora (Tiet i sur., 2001.; Buckner, Mezzacappa i Beardslee, 2003.).

lako su zaštitni čimbenici na razini zajednice manje istraživani od karakteristika djece i obitelji, pokazali su se važnima u proučavanju otpornosti. To su kvaliteta četvrti (Barbarin i sur., 2006.), kohezija u susjedstvu (Jaffee i sur., 2007.; Li, Nussbaum i Richards, 2007.), organizacije za mlade u zajednici (Cauce i sur., 2003.), kvaliteta školskog okruženja (Ozer i Weinstein, 2004.) te izvannastavne aktivnosti (Wyman, 2003.).

Što se tiče same prirode djelovanja otpornosti, istraživači se slažu da ona može varirati kroz vrijeme i područja života (Vanderbilt-Adriance i Shaw, 2008.). Na primjer, prilagodba može varirati tijekom vremena kako djeca doživljavaju različite događaje i s njima povezane izazove pa djeca koja doživljavaju veliku količinu različitih teškoća mogu dobro funkcionirati na društvenom i akademskom planu u školskoj dobi, ali pokazuju pogoršanje prilagodbe tijekom prijelaza u adolescenciju. Osim toga, djeca koja dobro funkcioniraju u jednom području, primjerice, školi, mogu iskazivati probleme u drugim područjima, primjerice, u razini depresivnosti (Luthar, Doernberger i Zigler, 1993.). S tim se slaže i Ajduković (2000.) kada upozorava da stavljanje djece u kategoriju otpornosti i generalizirane kompetentnosti može dovesti do toga da im ne pružamo adekvatnu količinu podrške jer smatramo da, zbog otpornosti, njihovi doživljaji nisu praćeni neugodnim emocijama. Prema 
tome, otpornost se ne može generalizirati na različita područja i dob djece, već je treba promatrati u specifičnim kontekstima, prilagođenima snagama i slabostima djece.

Kada govorimo o istraživanjima otpornosti u kontekstu ekonomskih teškoća, može se reći da ih ima relativno malo u usporedbi s drugim rizičnim čimbenicima (Buckner,MezzacappaiBeardslee,2003.).Tako semanjibrojistraživača bavioopćenito otpornošću djece koja odrastaju u ekonomski nepovoljnim prilikama ili otpornošću djece koja odrastaju u gradovima u unutrašnjosti SAD-a koja imaju izraženije ekonomske teškoće od ostatka te države (Luthar, 1991.; Luthar, Doernberger i Zigler, 1993.). Istraživači upozoravaju da je iznimno važno proučavati otpornost u ovom kontekstu, što zbog činjenice da velik broj djece živi u ekonomskim teškoćama, što zbog relevantnosti proučavanja otpornosti u svrhu kreiranja adekvatnih socijalnih politika usmjerenih na siromašne (Buckner, Mezzacappa i Beardslee, 2003.; KimCohen i sur., 2004.). Osim toga, djeca koja odrastaju u ekonomskim teškoćama, vrlo vjerojatno doživljavaju i druge oblike rizičnih čimbenika koji utječu na njihove psihosocijalne ishode (Fergusson, Swain-Campbell i Horwood, 2004.). Primjerice, odrastanje u dijelu grada u kojem većina kućanstava ima niske prihode povezana je s nižim stupnjem obrazovanja, druženjem s vršnjacima devijantnog ponašanja, smanjenim pristupom relevantnim resursima te višom razinom negativnih životnih događaja (Leventhal i Brooks-Gunn, 2000.).

To nas dalje vodi do istraživanja koja pokazuju da su takvi, kumulativni, rizici povezani s nizom negativnih ishoda te da se vjerojatnost negativnog ishoda povećava kako se povećava broj rizičnih čimbenika (Fergusson, Swain-Campbell i Horwood, 2004.). Tu je važno napomenuti određenu opreznost pri generaliziranju svih istraživanja otpornosti. Kako je već spomenuto, otpornost može varirati unutar jednog pojedinca, ovisno o području života i dobi djeteta, a sada vidimo i važnost broja različitih rizičnih čimbenika. Stoga istraživači ne preporučuju generaliziranje rezultata istraživanja o otpornosti na dominantno djeci bijelaca iz srednje klase na svu ostalu djecu. Izlaganjem takvom zaključivanju može dovesti do precjenjivanja razine otpornosti kod djece koja odrastaju izložena kroničnim i ozbiljnim rizičnim čimbenicima.

Time postaje važnije istraživati otpornost kod djece koja odrastaju u ekonomskim neprilikama na sveobuhvatan i relevantan način. Kao cjelokupni mehanizam proučavanja utjecaja zaštitnih i rizičnih faktora na prilagodbu djece i mladih, istraživanje otpornosti može imati niz implikacija na kreiranje konkretnih i usmjerenih intervencija na dugo proučavane rizične skupine djece i mladih.

\section{8 članci}




\section{ZAKLJUČAK}

Izučavanje utjecaja ekonomskih teškoća na psihosocijalne ishode mladih ima izuzetno važnu ulogu u svijetu opterećenom ekonomskom nejednakošću. To je i kompleksan zadatak koji podrazumijeva proučavanje niza čimbenika opisanih još u Bronfenbrennerovom modelu - od samog pojedinca do sustava države i kulture. U ovom radu pokušali smo pružiti pregled najviše istraživanih individualnih karakteristika u području ekonomskih teškoća.

Djeca koja odrastaju u ekonomskim teškoćama pokazuju niže rezultate na testovima inteligencije, znanja jezika te akademskog uspjeha, imaju veću vjerojatnost izgubiti godinu školovanja, pohađati posebne oblike obrazovanje ili napustiti školovanje, u usporedbi s djecom koja odrastaju u prosječnim ili iznadprosječnim ekonomskim uvjetima (McLoyd, 1998; Bradley i Corwyn, 2002.; Jefferis, Power i Hertzman, 2002.; Linver, Brooks-Gunn i Kohen, 2002.; McCulloch i Joshi, 2001.).

Istraživanja su pokazala da osobine ličnosti mogu predviđati psihosocijalne ishode djece i odraslih, ali nalazi nisu posve konzistentni u okviru petofaktorskog modela. Tako je dobivena negativna povezanost delinkventnog ponašanja s ugodnošću i savjesnošću, a pozitivna povezanost s neuroticizmom (John i sur., 1994.; Heaven, 1995.).

Eksternalizirani problemi negativno su povezani s ugodnošću i savjesnošću, a pozitivno $s$ ekstraverzijom, dok su internalizirani problemi pozitivno korelirani s neuroticizmom, a negativno sa savjesnošću (John i sur., 1994.). Školski uspjeh i inteligencija pozitivno su povezani s otvorenosti prema novim iskustvima, ugodnošću i savjesnošću (John i sur., 1994.; Poropat, 2009.).

Pod okvirom proučavanja otpornosti, karakteristike djeteta povezane s pozitivnim ishodima uključuju visoku inteligenciju, regulaciju emocija, temperament i ličnost $s$ karakteristikama adaptibilnosti i društvenosti, pozitivne strategije suočavanja, internalni lokus kontrole, adekvatnu pažnju i zdrave genetske utjecaje (Masten i Powell, 2003.).

Istraživači u društvenim, biomedicinskim i interdisciplinarnim znanostima imaju odgovornu ulogu kada se radi o proučavanju ekonomskih teškoća. $U$ istraživačkom okviru, postoji inicijativa Stop Skipping Class koji zagovara revnije uključivanje socioekonomskih obilježja sudionika istraživanja pri samom uzorkovanju, analizama te objavljivanju znanstvenih radova koji će doprinijeti tome da ljudi različitog financijskog statusa dobiju priliku za sudjelovanjem te time omogućiti reprezentativnije zaključke o različitim istraživačkim temama (Clay, 2015.). Osim odgovornosti prema proširivanju korpusa znanja u ovom području, možemo reći da je i još odgovornija uloga koja se otvara sa završetkom istraživanja i poticanjem kreatora socijalnih politika na aktivno mijenjanje okolnosti pojedinaca, obitelji i skupina pogođenih ekonomskim teškoćama. 


\section{LITERATURA}

1. Ajduković, M. (2001). Ekološki multidimenzionalni pristup sagledavanju činitelja rizika i zaštite u razvoju poremećaja u ponašanju djece i mladeži. U: Bašić, J. \& Janković, J. (ur.), Rizični i zaštitni čimbenici u razvoju poremećaja u ponašanju djece i mladeži. Zagreb: Povjerenstvo Vlade RH za prevenciju poremećaja u ponašanju djece i mladeži i zaštitu djece s poremećajima u ponašanju, 47-63.

2. Ajduković, M. \& Rajhvajn Bulat, L. (2012). Doživljaj financijskog statusa obitelji i psihosocijalno funkcioniranje srednjoškolaca. Revija za socijalnu politiku, 19 (3), 233-253.

3. Ajduković, M. \& Rajter, M. (2014). Obiteljski ekonomski stres kao čimbenik rizika za nasilne odgojne postupke i psihosocijalnu dobrobit djece. U: Brajša-Žganec, A., Lopižić, J. \& Penezić, Z. (ur.), Psihološki aspekti suvremene obitelji, braka i partnerstva. Jastrebarsko: Naklada Slap i Hrvatsko psihološko društvo, 353375.

4. Barbarin, O., Bryant, D., McCandies, T., Burchinal, M., Early, D., Clifford, R. \& Howes, C. (2006). Children enrolled in public pre-K: The relation of family life, neighborhood quality, and socioeconomic resources to early competence. American Journal of Orthopsychiatry, 76 (2), 265-276.

5. Bradley, R. H. \& Corwyn, R. F. (2002). Socioeconomic status \& child development. Annual Review of Psychology, 53, 371-399.

6. Branje, S. J., van Lieshout, C. F. \& Gerris, J. R. (2007). Big Five personality development in adolescence and adulthood. European Journal of Personality, 21 (1), 45-62.

7. Bronfenbrenner, U. (1979). The ecology of human development. Cambridge: Harvard University Press.

8. Buckner, J. C., Mezzacappa, E. \& Beardslee, W. R. (2003). Characteristics of resilient youths living in poverty: The role of self-regulatory processes. Development and Psychopathology, 15 (01), 139-162.

9. Caspi, A. (1998). Personality development across the life course. In: Damon, W. \& Eisenberg, N. (eds.), Handbook of child psychology: Social, emotional, and personality development (5th edition). New York: Wiley, 311-388.

10. Cauce, A. M., Stewart, A., Rodriquez, M. D., Cochran, B. \& Ginzler, J. (2003). Overcoming the odds. Adolescent development in the context of urban poverty. In: Luthar, S. S. (eds.), Resilience and vulnerability: Adaptation in the context of childhood adversities. NY: Cambridge University Press, 343-363.

11. Cauthen, N. K. \& Fass, S. (2008). Ten important questions about child poverty and family economic hardship. National Center for Children in Poverty. Preuzeto s: http://www.nccp.org (20.7.2016.). 
Ines Rezo: Uloga individualnih čimbenika u povezanosti ekonomskih teškoća...

11. Clay, R. A. (2015). Fighting poverty. Monitor on Psychology, 46 (7). Preuzeto s: http://www.apa.org/monitor/2015/07-08/cover-poverty.aspx (16.10.2016.).

12. Conger, R. D., Conger, K. J. \& Martin, J. M. (2010). Socioeconomic status, family processes, and individual development. Journal of Marriage and Family, 72 (3), 685-704.

13. Conger R. D. \& Donnellan, M. B. (2007). An interactionist perspective on the socioeconomic context of human development. Annual Review of Psychology, 58, 175-199.

14. Conger, R. D., Ge, X. J., Elder, G. H., Lorenz, F. O. \& Simons, R. L. (1994). Economic stress, coercive family process, and developmental problems of adolescents. Child Development, 65 (2), 541-561.

15. Conger R. D., Wallace L. E., Sun Y., Simons R. L., McLoyd, V. C. \& Brody, G. (2002). Economic pressure in African American families: A replication and extension of the family stress model. Developmental Psychology, 38 (2), 179-193.

16. Costa, P. T. \& McCrae, R. R. (1994). Set like plaster? Evidence for the stability of adult personality. In: Heatherton, T. \& Weinberger, J. L. (eds.), Can Personality Change? Washington, DC: American Psychological Association, 21-40.

17. D'Imperio, R. L., Dubow, E. F. \& Ippolito, M. F. (2000). Resilient and stressaffected adolescents in an urban setting. Journal of Clinical Child Psychology, 29 (1), 129-142.

18. Donnellan, M. B., Conger, K. J., McAdams, K. K. \& Neppl, T. K. (2009). Personal characteristics and resilience to economic hardship and its consequences: Conceptual issues and empirical illustrations. Journal of Personality, 77 (6), 1645-1676.

19. Essex, M. J., Thomas Boyce, W., Hertzman, C., Lam, L. L., Armstrong, J. M., Neumann, S.\& Kobor, M.S. (2013). Epigenetic vestiges of early developmental adversity: childhood stress exposure and DNA methylation in adolescence. Child Development, 84 (1), 58-75.

20. Fergusson, D. M., Swain-Campbell, N. R. \& Horwood, L. J. (2004). How does childhood economic disadvantage lead to crime? Journal of Child Psychology \& Psychiatry, 45 (5), 956-966.

21. Ferić, I., Milas, G. \& Rihtar, S. (2010). Razlozi i odrednice ranoga napuštanja školovanja, Društvena istraživanja, 19 (4-5), 621-642.

22. Galić, Z., Maslić Seršić, D. \& Šverko, B. (2006). Financijske prilike i zdravlje nezaposlenih u Hrvatskoj: Vodi li financijska deprivacija do lošijeg zdravlja? Revija za socijalnu politiku, 13 (3), 257-269.

23. Gorman-Smith, D., Henry, D. B. \& Tolan, P. H. (2004). Exposure to community violence and violence perpetration: The protective effects of family functioning. Journal of Clinical Child and Adolescent Psychology, 33 (3), 439-449. 
24. Gregurović, M. \& Kuti, S. (2010). Učinak socioekonomskog statusa na obrazovno postignuće učenika: Primjer PISA istraživanja, Hrvatska 2006. Revija za socijalnu politiku, 17 (2), 179-196.

25. Guo, G. (1998). The timing of the influences of cumulative poverty on children's cognitive ability and achievement. Social Forces, 77 (1), 257-287.

26. Guo, G. \& Harris, K. M. (2000). The mechanisms mediating the effects of poverty on children's intellectual development. Demography, 37 (4), 431-447.

27. Hackman, D. A., Gallop, R., Evans, G. W. \& Farah, M. J. (2015). Socioeconomic status and executive function: Developmental trajectories and mediation. Developmental Science, 18 (5), 686-702.

28. Heaven, P. C. L. (1996). Personality and self-reported delinquency: Analysis of the »Big Five« personality dimensions. Personality and Individual Differences, $20(1), 47-54$.

29. Heckman, J. J. (2008). The case for investing in disadvantaged young children. In: Focus, F. (ed.), Big ideas for children: Investing in our nation's future. Washington DC: First Focus, 49-58.

30. Jaffee, S. R., Caspi, A., Moffitt, T. E., Polo-Tomas, M. \& Taylor, A. (2007). Individual, family, and neighborhood factors distinguish resilient from non-resilient maltreated children: A cumulative stressors model. Child Abuse \& Neglect, 31 (3), 231-253.

31. Jefferis, B. J., Power, C. \& Hertzman, C. (2002). Birth weight, childhood socioeconomic environment, and cognitive development in the 1958 British birth cohort study. British Medical Journal, 325 (7359), 305.

32. John, O. P., Caspi, A., Robins, R. W., Moffitt, T. E. \& Stouthamer-Loeber, M. (1994). The »Little five«: Exploring the nomological network of the five-factor model of personality in adolescent boys. Child Development, 65 (1), 160-178.

33. Kim-Cohen, J., Moffitt, T. E., Caspi, A. \& Taylor, A. (2004). Genetic and environmental processes in young children's resilience and vulnerability to socioeconomic deprivation. Child Development, 75 (3), 651-668.

34. Kuterovac Jagodić, G., Keresteš, G. \& Brković, I. (2013). Osobni, obiteljski i okolinski prediktori školskoga uspjeha: Provjera moderatorske uloge odrastanja u ratom različito pogođenim područjima Hrvatske. Psihologijske teme, 22 (1), $1-28$.

34. Lager, A., Bremberg, S. \& Vagero, D. (2009). The association of early IQ and education with mortality: 65 year longitudinal study in Malmo, Sweden. British Medical Journal, 339, b5282.

36. Landers-Potts, M., Wickrama, K., Simons, L. G., Gibbons, F. \& Conger, R. (2015). An extension and moderational analysis of the family stress model. Family Relations, 64 (2), 233-248.

37. Larsen, R. J. \& Buss, D. M. (2008). Psihologija ličnosti. Jastrebarsko: Naklada Slap. 
Ines Rezo: Uloga individualnih čimbenika u povezanosti ekonomskih teškoća...

38. Leksikografski zavod Miroslav Krleža (2016). Hrvatska enciklopedija. Zagreb: Leksikografski zavod Miroslav Krleža. Preuzeto s: http://www.enciklopedija.hr/ (20.7.2016.).

39. Leventhal, T. \& Brooks-Gunn, J. (2000). The neighborhoods they live in: The effects of neighborhood residence on child and adolescent outcomes. Psychological Bulletin, 126 (2), 309-337.

40. Li, S. T., Nussbaum, K. M. \& Richards, M. H. (2007). Risk and protective factors for urban African-American youth. American Journal of Community Psychology, 39 (1-2), 21-35.

41. Linver, M. R., Brooks-Gunn, J. \& Kohen, D. E. (2002). Family processes as pathways from income to young children's development. Developmental Psychology, 38 (5), 719-734.

42. Lippman, L. H., Anderson Moore, K. \& Mclntosh, H. (2009). Positive indicators of child well-being: A conceptual framework, measures and methodological issues. innocenti working paper 2009-21. Florence: UNICEF Innocenti Research Centre.

43. Lubinski, D. (2004). Introduction to the Special Section on Cognitive Abilities: 100 Years After Spearman's (1904) »General Intelligence, Objectively Determined and Measured«. Journal of Personality and Social Psychology, 86 (1), 96-111.

44. Luthar, S. S. (1991). Vulnerability and resilience: A study of high-risk adolescents. Child development, 62 (3), 600-616.

45. Luthar, S. S. \& Cicchetti, D. (2000). The construct of resilience: Implications for interventions and social policies. Development and Psychopathology, 12 (4), 857-885.

46. Luthar, S. S., Cicchetti, D. \& Becker, B. (2000). The construct of resilience: A critical evaluation and guidelines for future work. Child Development, 71 (3), 543-562.

47. Luthar, S. S., Doernberger, C. H. \& Zigler, E. (1993). Resilience is not a unidimensional construct: Insights from a prospective study of inner-city adolescents. Development and Psychopathology, 5 (4), 703-717.

48. Luthar, S. S. \& Latendresse, S. J. (2005). Comparable »risks« at the socioeconomic status extremes: Preadolescents' perceptions of parenting. Development and Psychopathology, 17 (1), 207-230.

49. Luthar, S. S. \& Sexton, C. C. (2007). Maternal drug abuse versus maternal depression: Vulnerability and resilience among school-age and adolescent offspring. Development and Psychopathology, 19 (01), 205-225.

50. Luthar, S. S. \& Zelazo, L. B. (2003). Research on resilience: An integrative review. In: Luthar, S. S. (ed.), Resilience and vulnerability: Adaptation in the context of childhood adversities. New York: Cambridge University Press, 511-549. 
Ljetopis socijalnog rada 2016., 23 (2), 165-186 str.

51. Masten, A. S. (2007). Resilience in developing systems: Progress and promise as the fourth wave rises. Development and Psychopathology, 19 (3), 921-930.

52. Martikainen, P., Bartley, M. \& Lahelma, E. (2002). Psychosocial determinants of health in social epidemiology. International Journal of Epidemiology, 31 (6), 1091-1093.

53. Masten, A. S. \& Coatsworth, J. D. (1998). The development of competence in favorable and unfavorable environments: Lessons from successful children. American Psychologist, 53 (2), 205-220.

54. Masten, A. S. \& Powell, J. L. (2003). A resilience framework for research, policy, and practice. In: Luthar, S. S. (ed.), Resilience and vulnerability: Adaptation in the context of childhood adversities. New York: Cambridge University Press, 1-25.

55. Masten, A. S. (2001). Ordinary magic: Resilience processes in development. American Psychologist, 56 (3), 227-238.

56. Masten, A. S. \& Reed, M. J. (2002). Resilience in development. In: Snyder, C. R. \& López, S. J. (eds.), Handbook of positive psychology. New York: Oxford University Press, 74-88.

57. McCulloch, A. \& Joshi, H. E. (2001). Neighbourhood and family influences on the cognitive ability of children in the British National Child Development Study. Social Science \& Medicine, 53 (5), 579-591.

58. McEwen, B. S. (2008). Central effects of stress hormones in health and disease: Understanding the protective and damaging effects of stress and stress mediators. European Journal of Pharmacology, 583 (2), 174-185.

59. McGue, M., Bacon, S. \& Lykken, D. T. (1993). Personality stability and change in early adulthood: A behavioral genetic analysis. Developmental Psychology, 29 (1), 96-109.

60. McLeod, J. D. \& Shanahan, M. J. (1993). Poverty, parenting, and children's mental health. American Sociological Review, 58, 351-366.

61. McLoyd, V. C. (1998). Socioeconomic disadvantage and child development. American Psychologist, 53 (2), 185-204.

62. Ozer, E. J. \& Weinstein, R. S. (2004). Urban adolescents' exposure to community violence: The role of support, school safety, and social constraints in a school-based sample of boys and girls. Journal of Clinical Child and Adolescent Psychology, 33 (3), 463-476.

63. Poropat, A. (2009). A meta-analysis of the five-factor model of personality and academic performance article. Psychological Bulletin, 135 (2), 322-338.

64. Raboteg-Šarić, Z., Brajša-Žganec, A. \& Šakić, M. (2009). Life satisfaction in adolescents: The effects of perceived family economic status, self-esteem and quality of family and peer relationship. Društvena istraživanja, 3 (101), 547-564. 
Ines Rezo: Uloga individualnih čimbenika u povezanosti ekonomskih teškoća...

65. Roberts, B. W., Caspi, A. \& Moffitt, T. E. (2003). Work experiences and personality development in young adulthood. Journal of personality and social psychology, 84(3), 582-593.

66. Roberts, B. W., Kuncel, N. R., Shiner, R., Caspi, A. \& Goldberg, L. R. (2007). The power of personality: The comparative validity of personality traits, socioeconomic status, and cognitive ability for predicting important life outcomes. Perspectives on Psychological Science, 2 (4), 313-345.

67. Seifer, R., Sameroff, A. J., Baldwin, C. P. \& Baldwin, A. (1992). Child and family factors that ameliorate risk between 4 and 13 years of age. Journal of the American Academy of Child \& Adolescent Psychiatry, 31 (5), 893-903.

68. Šućur, Z., Kletečki Radović, M., Družić Ljubotina, O. \& Babić, Z. (2015). Siromaštvo i dobrobit djece predškolske dobi u Republici Hrvatskoj. Zagreb: Ured UNICEF-a za Hrvatsku.

69. Tiet, Q. Q., Bird, H. R., Hoven, C. W., Wu, P., Moore, R. \& Davies, M. (2001). Resilience in the face of maternal psychopathology and adverse life events. Journal of Child and Family Studies, 10 (3), 347-365.

70. Wagnild, G. M. \& Young, H. M. (1993). Development and psychometric evaluation of the Resilience Scale. Journal of Nursing Measurement, 1 (2), 165-178.

71. Vanderbilt-Adriance, E. \& Shaw, D. S. (2008). Conceptualizing and re-evaluating resilience across levels of risk, time, and domains of competence. Clinical Child and Family Psychology Review, 11 (1-2), 30-58.

72. White, J. L., Moffitt, T. E. \& Silva, P. A. (1989). A prospective replication of the protective effects of IQ in subjects at high risk for juvenile delinquency. Journal of Consulting and Clinical Psychology, 57 (6), 719-724.

73. World Health Organization (1948). WHO definiton of health. Preuzeto s: http://www.who.int/about/definition/en/print.html (12.10.2016.).

74. Wyman, P. A. (2003). Emerging perspectives on context specificity of children's adaptation and resilience: Evidence from a decade of research with urban children in adversity. In: Luthar, S. S. (ed.), Resilience and Vulnerability: Adaptation in the Context of Childhooed Adversities. New York: Cambridge University Press, 293-317.

75. Yule, W., Stuvland, R., Baingana, F. K. \& Smith, P. (2004). Children in armed conflict. In: Green, B. L. (ed.), Trauma interventions in war and peace: Prevention, practice, and policy. New York, NY: Kluwer Academic Publishers, 217-242. 
Ljetopis socijalnog rada 2016., 23 (2), 165-186 str.

Ines Rezo

University of Zagreb

Faculty of Law

Department of Social Work

\title{
ECONOMIC HARDSHIP AND OUTCOMES IN ADOLESCENCE: THE ROLE OF INDIVIDUAL FACTORS'
}

\begin{abstract}
In social sciences there is a long tradition of studying how economic hardship influences life and personal development of individuals. Poverty and economic hardship of families are related to a series of externalized and internalized problems of young people, as well as to their educational outcomes. Alongside important family processes and other social and contextual processes relevant for that relationship, individual characteristics of children, adolescents and parents also play an important role. The paper focuses on an overview of recent findings on the role of cognitive skills, personality and endurance of children and young people in relation to economic hardship and their educational outcomes. Particular emphasis is placed on the responsibility of social, biomedical and interdisciplinary scientists dealing with economic hardship and how it influences the development of social policies and active measures aimed at individuals struck by economic hardship.
\end{abstract}

Key words: family economic hardship, psycho-social outcomes, safety and risk factors, adolescents.

\footnotetext{
${ }^{1}$ This paper was funded by the Croatian Science Foundation through the project »Family Economic Hardship, Psycho-social Issues and Educational Outcomes of Adolescents in Times of Economic Crisis" [IP-2014-098546].
}

\section{6 članci}

